\title{
Czas wolny i aktywność społeczna starszych wiekiem mieszkańców Białegostoku
}

\begin{abstract}
Abstrakt
Artykuł oparty jest na materiale pochodzącym z badań ankietowych przeprowadzonych wśród osób starszych (65+) zamieszkałych w Białymstoku. Jego celem jest analiza sytuacji obecnej oraz zarejestrowanie zmian, które zaszły w obszarze aktywności społecznej seniorów na przestrzeni dwudziestu lat. Okazuje się, że bardziej aktywne w starości są osoby zdrowsze, lepiej wykształcone, z lepszym zabezpieczeniem materialnym, zadowolone z życia. Aktywność społeczna jest też bardziej domeną kobiet niż mężczyzn oraz w większym stopniu dotyczy seniorów z młodszych kohort wieku.
\end{abstract}

Słowa kluczowe: ludzie starzy, aktywność, czas wolny.

\section{Free Time and Social Activity of Elderly Residents of Białystok}

\begin{abstract}
The paper is based on surveys conducted among elderly people (65+) living in Białystok. Its aim is to analyze the current situation and changes that have occurred in the area of social activity of seniors over the last twenty years. It is shown that elderly people who are healthy and educated individuals, with sufficient material security and, in general, satisfied with life are more active. It also occurs that women participate more often in social activities than men; the same applies to seniors from the younger age cohorts.
\end{abstract}

Keywords: elderly people, activity, free time.

\footnotetext{
* Uniwersytet w Białymstoku.
} 


\section{Wprowadzenie}

Peter Baltes (1996) twierdzi, że starość jest okresem, w którym straty zaczynają przewyższać zyski. Nie oznacza to jednak, że w tym okresie życia nie ma już nic do zyskania. Człowiek starszy ma już zazwyczaj uładzone sprawy rodzinne (usamodzielnione dzieci) i zawodowe (emerytura), a przez to zyskuje coraz więcej czasu wolnego. Czas wolny charakteryzuje się tym, że nic w nim nie musimy, a wszystko możemy. Jednak żeby móc, trzeba chcieć. I to jest cała tajemnica sensownego zagospodarowania czasu wolnego. Czas wolny w starości może być czasem pomyślnym lub niepomyślnym. Czasem pomyślnym staje się wówczas, gdy jest w rozsądny sposób wykorzystywany z zyskiem dla siebie i innych, i wtedy najczęściej pojawia się jego deficyt. Czasem niepomyślnym zaś jest wówczas, gdy przeciekając między palcami nie pozostawia po sobie żadnych śladów czy efektów, i wiąże się to z coraz większym jego nadmiarem. Brak czasu jest konsekwencją postawy aktywnej, a nadmiar pasywności. W odniesieniu do używanych w literaturze pedagogicznej definicji, czas wolny rozumiany będzie w niniejszych rozważaniach jako czas wypełniony czynnościami posiadającymi znamiona dobrowolności i niekomercyjności, których wykonywanie jest źródłem satysfakcji (Czerepaniak-Walczak 2007). Czas wolny konstytuowany jest więc przez trzy elementy: dobrowolność, niezarobkowość i przyjemność (satysfakcję). W pracach systematyzujących wiedzę na temat czasu wolnego zastosowane w niniejszym tekście rozumienie tego pojęcia mieści się w obszarze funkcjonalnym (Czerepaniak-Walczak 2007) oraz autonomiczno-osobistym i normatywno-funkcjonalnym (Gagacka 2007).

Badania dotyczące czasu wolnego i aktywności społecznej ludzi starszych w Polsce mają stosunkowo obszerną literaturę. W miarę kompletną bibliografię na ten temat znajdzie czytelnik w pracach: J. Piotrowskiego (1973), M. Halickiej i J. Halickiego (2002), M. Mossakowskiej, A. Więcka i P. Błędowskiego (2012), B. Gosik (2016) i D. Rynkowskiej (2016). Warte wymienienia są ogólnopolskie badania nad jakością życia ludzi starych w Polsce, prowadzone przez zespół prof. Jerzego Piotrowskiego w latach 1964-1968, w ramach których poruszana była też problematyka czasu wolnego i aktywności ludzi starych. Ponad czterdzieści lat później, w latach 1999-2001, podobne badania przeprowadziła grupa badaczy skupiona wokół prof. Brunona Synaka w ramach grantu Polskiego Towarzystwa Gerontologicznego. Również ogólnopolski projekt badawczy PolSenior, którego wyniki ukazały się drukiem w 2012 r. zawierał rezultaty badań dotyczących pewnych aspektów czasu wolnego i aktywności społecznej ludzi starych.

\section{Metodologia badań}

Prezentowany artykuł został oparty na badaniach prowadzonych w 2019 r. w Białymstoku. Badania objęły reprezentatywną grupę 980 osób (601 kobiet i 379 mężczyzn) w wieku 65+ mieszkańców stolicy województwa podlaskiego. Liczeb- 
ność poszczególnych grup wiekowych (65-69, 70-74, 75-79, 80 i więcej lat) oraz proporcja kobiet do mężczyzn odzwierciedla realny udział poszczególnych grup w populacji mieszkańców Białegostoku. Zachowano również podział terytorialny na 28 dzielnic miasta, proporcjonalnie do ich liczebności. Badania zostały przeprowadzone przez przeszkolonych ankieterów w oparciu o standaryzowany wywiad kwestionariuszowy online/PAPI, wśród wybranych metodą Random Route mieszkańców miasta Białegostoku. Biorący udział w przedsięwzięciu ankieterzy zostali przeszkoleni w Pracowni Badań, Analiz i Strategii Edukacji Centrum Kształcenia Ustawicznego w Białymstoku. Zastosowane w badaniach narzędzie badawcze dotyczące czasu wolnego i aktywności społecznej zostało opracowane na podstawie kwestionariusza ankiety pochodzącego z badań prowadzonych przez zespół Polskiego Towarzystwa Gerontologicznego kierowanego przez prof. B. Synaka, którego członkiem był autor niniejszej publikacji. Celem artykułu jest ukazanie zmian w zakresie zagospodarowywania czasu wolnego i wykazywanej aktywności społecznej przez ludzi starszych, które zaszły w środowisku polskich seniorów na przestrzeni dwudziestu lat oraz wskazanie pewnych problemów z tych zmian wynikających.

\section{Czas wolny starszych wiekiem mieszkańców Białegostoku}

W rozważaniach na temat czasu wolnego starszych wiekiem mieszkańców Białegostoku należy zacząć pytaniem: ile czasu mogą poświęcić dla siebie? Brak lub nadmiar czasu jest, do pewnego stopnia, wskaźnikiem zaangażowania społecznego i aktywności. Zdecydowana większość opisała to kategorią „w sam raz” (68,5\%), prawie co siódmy badany $(15,1 \%)$ twierdzi, że ma czasu za dużo, a 8,2\% seniorów narzeka na deficyt czasu (tabela 1 ).

Tabela 1. Ilość czasu wolnego, który osoby starsze mogą poświęcić dla siebie

\begin{tabular}{|l|c|c|}
\hline $\begin{array}{l}\text { Ile ma Pan/Pani czasu, który może Pan/Pani } \\
\text { poświęcić dla siebie? }\end{array}$ & $\mathrm{N}$ & $\%$ \\
\hline Za mało & 80 & 8,2 \\
\hline Za dużo & 148 & 15,1 \\
\hline W sam raz & 671 & 68,5 \\
\hline Trudno powiedzieć & 81 & 8,3 \\
\hline Ogółem & 980 & 100,0 \\
\hline
\end{tabular}

Źródło: badania własne. 
W porównaniu z prowadzonymi przed dwudziestu laty badaniami ogólnopolskimi obserwujemy pozytywne zmiany. Prawie 30\% badanych twierdziło wówczas, że ma czasu za dużo, zaś 5\% uskarżało się na brak czasu (Halicka, Halicki 2002). Wydaje się, że wchodzące w okres starości nowe kohorty ludzi starszych są coraz lepiej przygotowane do zagospodarowywania wolnego czasu, chociaż z drugiej strony różnicę tę należy też przyjmować z pewną ostrożnością, ponieważ cytowane badania ogólnopolskie były prowadzone w dużych miastach, małych miejscowościach i na wsi. Jednak za miarodajnością takiego porównania przemawia fakt, że Białystok jest miastem silnie zruraryzowanym. Duża część jego mieszkańców pochodzi z okolicznych miasteczek i wsi (Sadowski 1981, 2006).

Tabela 2. Ilość czasu wolnego, który osoby starsze mogą poświęcić dla siebie a wiek badanych

\begin{tabular}{|c|c|c|c|c|c|c|c|c|c|c|}
\hline \multirow{3}{*}{$\begin{array}{l}\text { Ile ma Pan/Pani } \\
\text { czasu, który może } \\
\text { Pan/Pani poświęcić } \\
\text { dla siebie? }\end{array}$} & \multicolumn{10}{|c|}{ Wiek } \\
\hline & \multicolumn{2}{|c|}{$65-69$} & \multicolumn{2}{|c|}{$70-74$} & \multicolumn{2}{|c|}{$75-79$} & \multicolumn{2}{|c|}{80 i więcej } & \multicolumn{2}{|c|}{ ogółem } \\
\hline & $\mathrm{N}$ & $\%$ & $\mathrm{~N}$ & $\%$ & $\mathrm{~N}$ & $\%$ & $\mathrm{~N}$ & $\%$ & $\mathrm{~N}$ & $\%$ \\
\hline Za mało & 51 & 11,7 & 16 & 6,6 & 7 & 4,2 & 6 & 4,3 & 80 & 8,2 \\
\hline Za dużo & 40 & 9,2 & 37 & 15,4 & 30 & 18,2 & 41 & 29,7 & 148 & 15,1 \\
\hline W sam raz & 318 & 72,9 & 161 & 66,8 & 119 & 72,1 & 73 & 52,9 & 671 & 68,5 \\
\hline Trudno powiedzieć & 27 & 6,2 & 27 & 11,2 & 9 & 5,5 & 18 & 13,0 & 81 & 8,3 \\
\hline Ogółem & 436 & 100,0 & 241 & 100,0 & 165 & 100,0 & 138 & 100,0 & 980 & 100,0 \\
\hline
\end{tabular}

Źródło: badania własne.

Interesująco wygląda rozkład odpowiedzi dotyczący czasu, który badani mogą poświęcić sobie w rozbiciu na kategorie wiekowe (tabela 2). Związek ten ma bardzo wysoki stopień istotności statystycznej $(\mathrm{p}=0.000)$. Im starsza grupa badanych, tym mniej narzekań, że czasu tego jest zbyt mało. W grupie wieku 65-69 ci, którym czasu jest zbyt mało, stanowią 11,7\%, lecz już w następnej kohorcie (70-74 lat) grupa ta maleje do $6,6 \%$, by w momencie wejścia w późną starość (75-79 lat) ustabilizować się na poziomie $4,2 \%$ oraz $4,3 \%$ (w grupie 81 lat i więcej). Natomiast grupa osób twierdzących, że czasu mają za dużo w kolejnych starszych kohortach wzrasta. We wczesnej starości (65-69 lat) narzekający na nadmiar czasu stanowią 9,2\%. W kolejnych grupach wieku odsetek ten wzrasta do 15,4\% (70-74 lat), $18,2 \%$ (75-79 lat), by w grupie najstarszej (80 lat i więcej) osiągnąć poziom prawie jednej trzeciej liczebności tej grupy wieku (29,7\%). Ten wzrost odbywa się kosztem zmniejszania się grupy badanych, którzy twierdzą, że czasu mają w sam raz.

W przytaczanych już badaniach ogólnopolskich prowadzonych przed dwudziestu laty notujemy podobną tendencję zmniejszania się deficytu czasu i zwiększania się jego nadmiaru w starszych kohortach wieku, przy czym deficyt był 
mniejszy niż w badaniach białostockich (8 do 3\%), a nadmiar większy (22 do 40\%) (Halicka, Halicki 2002). Wydaje się, że zjawisko nadmiaru wolnego czasu jest ważnym wyzwaniem dla różnych podmiotów zajmujących się zagospodarowywaniem czasu wolnego działających na terenie Białegostoku.

Nadmiar wolnego czasu to zjawisko dotykające przede wszystkim ludzi o niskim poziomie wykształcenia. Jedna czwarta seniorów z wykształceniem podstawowym narzeka na nadmiar czasu. Grupa deklarująca wykształcenie zawodowe określająca swój budżet czasu jako zbyt duży maleje w porównaniu z poprzednią do $18,1 \%$. Jeszcze mniejszy nadmiar czasu jest w grupie legitymującej się wykształceniem średnim (12\%), a najmniejszy nawis czasu wolnego deklarują absolwenci wyższych uczelni (9,5\%). Również z poziomem wykształcenia związany jest deficyt czasu, który można poświęcić dla siebie. Osoby z najniższym wykształceniem, którym czasu brakuje, stanowią tylko 3\% całej tej zbiorowości, a seniorzy z dyplomem wyższej uczelni, narzekający na deficyt czasu stanowią 13,1\% tej grupy.

Spójrzmy jeszcze na problem wolnego czasu przez pryzmat stanu cywilnego. Mężatki i żonaci częściej narzekają na brak czasu (12,2\%), a panny i kawalerowie oraz wdowy i wdowcy na jego nadmiar, odpowiednio: 20,6\% i 25,8\%. Te ostatnie informacje nie stanowią oczywiście jakiegoś specjalnego odkrycia, ale dobrze dopełniają obraz całej sytuacji. Wyniki badań ogólnopolskich prowadzonych na przełomie wieków również wskazują na podobne związki statystyczne (Halicka, Halicki 2002).

Tabela nr 3. Stopień osobistego włączania się ludzi starych w życie miejscowej społeczności

\begin{tabular}{|l|c|c|}
\hline \multicolumn{1}{|c|}{$\begin{array}{c}\text { Czy osobiście włącza się Pan/Pani w życie miejscowej } \\
\text { społeczności? }\end{array}$} & $\mathrm{N}$ & $\%$ \\
\hline $\begin{array}{l}\text { Tak, staram się razem z innymi poprawiać pewne rzeczy } \\
\text { w sąsiedztwie }\end{array}$ & 140 & 14,5 \\
\hline Jeszcze nie, ale od pewnego czasu myślę o tym & 137 & 14,2 \\
\hline Nie, nie widzę takiej potrzeby & 432 & 44,6 \\
\hline Nie, nie jestem w stanie aktywnie działać & 115 & 11,9 \\
\hline Nie, bo i tak nic nie da się zmienić & 51 & 5,3 \\
\hline Nie, nie interesuje mnie to & 93 & 9,6 \\
\hline Ogółem & 968 & 100,0 \\
\hline
\end{tabular}

Źródło: badania własne.

Reasumując kwestię czasu wolnego, trzeba podkreślić, że trudnym do rozwiązania problemem jest powiększanie się przestrzeni niechcianego czasu wolnego, czasu, który zamiast stanowić błogosławieństwo, może stać się przekleństwem. Nadmiar wolnego czasu dotyczy grup, które charakteryzują się cechami utrudniają- 
cymi podejmowanie jakichkolwiek działań animacyjnych. Dotyczy to grupy ludzi najstarszych, czyli najczęściej ludzi o słabym zdrowiu i z kłopotami lokomocyjnymi oraz grupy osób najgorzej wykształconych.

\section{Zaangażowanie społeczne starszych wiekiem mieszkańców Białegostoku}

Jednym ze sposobów zagospodarowywania wolnego czasu przez ludzi starszych jest włączanie się w życie społeczności lokalnej. Badanym osobom zadano pytanie dotyczące osobistego włączania się w życie miejscowej społeczności (tabela 3). Postawę aktywną zadeklarowało 14,5\% badanych. Starają się oni poprawić pewne rzeczy w najbliższej okolicy. Podobnej wielkości grupa seniorów $(14,2 \%)$ już od pewnego czasu myśli o włączeniu się w podobne działania. Jednak największa grupa respondentów (44,6\%) nie widzi potrzeby włączania się w aktywne działania na rzecz społeczności lokalnej. Niewielka grupka badanych $(5,3 \%)$ nie chce się włączyć w działania, bo nie wierzy, że to cokolwiek zmieni, zaś 11,9\% respondentów nie jest już w stanie działać. Prawie co dziesiąta osoba badana $(9,6 \%)$ przyjmuje postawę désintéressement wobec tego, co dzieje się w najbliższym otoczeniu.

Postawa osób starszych wobec spraw dziejących się w społeczności lokalnej od czasu prowadzonych przez Polskie Towarzystwo Gerontologiczne badań ogólnopolskich w latach 1999-2001 uległa dość istotnym zmianom. Znacznie zmniejszyła się grupa osób zupełnie niezainteresowana tym, co dzieje się w sąsiedztwie z 31,6\% respondentów w badaniach prowadzonych przez Polskie Towarzystwo Gerontologiczne do 9,6\% uczestników badań prowadzonych w Białymstoku. Podwoiła się też grupa osób aktywnie działająca na rzecz społeczności lokalnej z 7,8\% (badania PTG - 1999) do 14,5\% (badania w Białymstoku - 2019), a grupa osób gotowych podjąć działania zwiększyła się z 0,7 do 14,2\%. Postawę niewiary w pozytywne skutki działania wyrażało 16,7\% respondentów w 1999 roku i 9,6\% w roku 2019. A zatem uruchomiona została większa aktywność seniorów na rzecz małych ojczyzn, zmniejszyły się: obojętność oraz niewiara w skuteczność działania. Jest to niewątpliwie skutek wchodzenia w wiek emerytalny nowych grup, których członkowie doświadczali początków transformacji ustrojowej jako trzydziestoi czterdziestolatkowie. Są to osoby lepiej wykształcone i mniej obciążone postawą bierną i roszczeniową. I jeszcze jedna, ważna zmiana. Coraz większą aktywność wykazują kobiety. Swoje zaangażowanie w pracy na rzecz społeczności lokalnej deklarowało przed laty (badania z 1999 r.) 12\% mężczyzn i 6\% kobiet. W przeprowadzonych w Białymstoku w 2019 r. badaniach swoją aktywność zadeklarowało 15,2\% kobiet i 13,3\% mężczyzn. Nastąpiła więc eksplozja aktywności kobiet, podczas gdy wśród mężczyzn pozostała ona na podobnym poziomie. Nie mam żadnych wątpliwości, że wiąże się to ze zmianami obyczajowymi. Wielkim kataliza- 
torem tych zmian świadomościowych były pozytywne zmiany w zakresie infrastruktury i środowiska gospodarczo-społecznego. Niewątpliwie rację miał K. Marks twierdząc, że byt kształtuje świadomość.

Tabela 4. Stopień osobistego włączania się ludzi starych w życie miejscowej społeczności a wiek badanych

\begin{tabular}{|l|c|c|c|c|c|c|c|c|c|c|}
\hline \multirow{2}{*}{$\begin{array}{l}\text { Czy osobiście włącza } \\
\text { się Pan/Pani } \\
\text { w życie miejscowej } \\
\text { społeczności? }\end{array}$} & \multicolumn{2}{|c|}{$65-69$} & \multicolumn{2}{|c|}{$70-74$} & \multicolumn{2}{|c|}{$75-79$} & \multicolumn{2}{c|}{80 i więcej } & \multicolumn{2}{|c|}{ ogółem } \\
\cline { 2 - 11 } & $\mathrm{N}$ & $\%$ & $\mathrm{~N}$ & $\%$ & $\mathrm{~N}$ & $\%$ & $\mathrm{~N}$ & $\%$ & $\mathrm{~N}$ & $\%$ \\
\hline $\begin{array}{l}\text { Tak, staram się razem } \\
\text { z innymi poprawiać } \\
\text { pewne rzeczy } \\
\text { w sąsiedztwie }\end{array}$ & 69 & 16,0 & 37 & 15,7 & 24 & 14,5 & 10 & 7,3 & 140 & 14,5 \\
\hline $\begin{array}{l}\text { Jeszcze nie, ale od } \\
\text { pewnego czasu } \\
\text { myślę o tym }\end{array}$ & 82 & 19,1 & 38 & 16,1 & 16 & 9,7 & 1 & 0,7 & 137 & 14,2 \\
\hline $\begin{array}{l}\text { Nie, nie widzę takiej } \\
\text { potrzeby }\end{array}$ & 205 & 47,7 & 101 & 42,8 & 68 & 41,2 & 58 & 42,3 & 432 & 44,6 \\
\hline $\begin{array}{l}\text { Nie, nie jestem } \\
\text { w stanie aktywnie } \\
\text { działać }\end{array}$ & 25 & 5,8 & 21 & 8,9 & 22 & 13,3 & 47 & 34,3 & 115 & 11,9 \\
\hline $\begin{array}{l}\text { Nie, bo i tak nic nie da } \\
\text { się zmienić }\end{array}$ & 19 & 4,4 & 16 & 6,8 & 13 & 7,9 & 3 & 2,2 & 51 & 5,3 \\
\hline $\begin{array}{l}\text { Nie, nie interesuje } \\
\text { mnie to }\end{array}$ & 30 & 7,0 & 23 & 9,7 & 22 & 13,3 & 18 & 13,1 & 93 & 9,6 \\
\hline Ogółem & 430 & 100,0 & 236 & 100,0 & 165 & 100,0 & 137 & 100,0 & 968 & 100,0 \\
\hline
\end{tabular}

Źródło: badania własne.

Aktywne włączanie się w życie miejscowej społeczności jest silnie powiązane $\mathrm{z}$ wiekiem ( $\mathrm{p}=0.000$ ) (tabela 4). Spośród respondentów z najmłodszej kohorty 16\% deklaruje działania na rzecz społeczności lokalnej, 19,1\% badanych z tej samej kohorty myśli od pewnego czasu o podjęciu takich działań. Jednak wraz z wiekiem aktywność powoli maleje. W kolejnych dwóch grupach wieku (70-74 i 75-79 lat) aktywne angażowanie się w działania na rzecz społeczności deklaruje odpowiednio $15,7 \%$ i 14,5\% badanych, zaś o gotowości do działania mówi 16,1\% i 9,7\% respondentów z tych grup wieku. Najmniej aktywni są członkowie najstarszej kohorty (80 lat i więcej). 0 aktywnym włączaniu się w działania na rzecz społeczności lokalnej wspomina 7,3\% badanych, a o gotowości do tych działań tylko $0,7 \%$. Wraz $\mathrm{z}$ wiekiem maleje zainteresowanie działaniami na rzecz poprawiania pewnych 
rzeczy w sąsiedztwie. W najmłodszej grupie wieku (65-69 lat) postawę zupełnego braku zainteresowania przejawia 7\% seniorów, a w najstarszej (80 lat i więcej) 13,1\% badanych. Zwiększa się też wraz z wiekiem grupa osób, które nie są już w stanie aktywnie działać, od 5,8\% w najmłodszej grupie (65-69 lat), po 34,3\% w grupie najstarszej (80 lat i więcej).

Stopień włączania się w życie miejscowej społeczności wykazuje silny związek statystyczny z wykształceniem $(\mathrm{p}=0.000)$. Jest on widoczny szczególnie $w$ deklaracji aktywnego działania na rzecz społeczności lokalnej oraz wyrażenia gotowości do takich działań. Wśród osób z wykształceniem podstawowym deklarację działania na rzecz społeczności lokalnej złożyło 6,7\% badanych. Grupa osób aktywnych posiadających wykształcenie zawodowe powiększyła się o 2 punkty procentowe $(8,7 \%)$, natomiast wśród osób z wykształceniem średnim aktywne działania na rzecz społeczności lokalnej świadczy 15,2\% respondentów. Najbardziej aktywne są osoby najlepiej wykształcone. Jedna czwarta badanych seniorów z wykształceniem wyższym $(25,5 \%)$ zadeklarowała działania na rzecz poprawienia pewnych rzeczy w sąsiedztwie. Podobną tendencję obserwujemy wśród osób, które nie są w tej chwili aktywne, ale wyrażają gotowość działania. Taką postawę deklaruje 4,8\% seniorów z wykształceniem podstawowym, 11,3\% z wykształceniem zawodowym, 16,3\% posiadających wykształcenie średnie oraz 20,8\% badanych legitymujących się dyplomem wyższej uczelni. Deklarację, że nie są w stanie działać składa 18,2\% badanych z wykształceniem podstawowym i o połowę mniej do 9,3\% seniorów z wykształceniem wyższym. Również wielkość grupy wskazującej na brak zainteresowania działaniami na rzecz społeczności lokalnej zmniejsza się wraz z podwyższaniem się poziomu wykształcenia. Désintéressement dla zaangażowania w sprawy społeczności lokalnej zgłasza 15,8\% respondentów z wykształceniem podstawowym i 8,3\% badanych absolwentów szkół wyższych.

Okazuje się również, że aktywne działanie na rzecz społeczności lokalnej jest postawą częściej występującą u osób zadowolonych z aktualnego życia (19,9\% osób z tej grupy deklaruje aktywne działania) niż u osób niezadowolonych. Spośród tej ostatniej grupy tylko 2,4\% badanych mówi o aktywnym działaniu na rzecz poprawy pewnych rzeczy w sąsiedztwie. Postawę bierną motywowaną brakiem możliwości aktywnego działania na rzecz społeczności lokalnej przyjmuje 8,2\% osób zadowolonych z życia i 19,5\% niezadowolonych.

Deklarowana aktywność na rzecz społeczności lokalnej jest też w sposób istotny powiązana $\mathrm{z}$ sytuacją materialną badanych seniorów $(\mathrm{p}=0.001)$. Im lepsza sytuacja materialna respondentów, tym większa grupa osób aktywnych. Aktywne działania na rzecz społeczności lokalnej deklaruje 22,8\% osób oceniających swoją sytuację materialną jako bardzo dobrą, 17,2\% badanych twierdzących, że są w raczej dobrej sytuacji materialnej, 13,6\% oceniających swoje położenie jako przeciętne oraz tylko 3,1\% nazywających swoją kondycję finansową złą. Brak zainteresowania działaniami na rzecz społeczności lokalnej również wiąże się z deklarowanym poziomem zabezpieczenia materialnego. Tylko 3,5\% badanych 
o najwyższym poziomie zabezpieczenia materialnego nie jest zainteresowanych działaniami na rzecz społeczności lokalnej, podczas gdy wśród oceniających swoją kondycję finansową jako zła osoby niezainteresowane takimi działaniami stanowią $13,5 \%$.

Na koniec rzecz oczywista, aktywne działanie na rzecz społeczności lokalnej jest silnie związane $z$ deklarowanym przez badanych stanem zdrowia $(p=0.000)$. Im lepszy stan zdrowia, tym liczniejsza grupa osób działających na rzecz społeczności lokalnej. W grupie ze zdrowiem określanym jako dobre działa aktywnie 17,8\% badanych, w kohorcie gromadzącej osoby ze zdrowiem przeciętnym aktywność deklaruje 14,4\%, a w grupie o najsłabszym stanie zdrowia (zły i raczej zły) działa aktywnie na rzecz społeczności lokalnej $8,6 \%$ badanych.

Tabela 5. Udział w imprezach organizowanych w mieście

\begin{tabular}{|l|c|c|}
\hline $\begin{array}{c}\text { Czy Pan/Pani uczestniczy w imprezach/ } \\
\text { festynach organizowanych w mieście? }\end{array}$ & N & $\%$ \\
\hline Tak & 579 & 59,1 \\
\hline Nie & 401 & 40,9 \\
\hline Ogółem & 980 & 100,0 \\
\hline
\end{tabular}

Źródło: badania własne.

Aktywne uczestnictwo w życiu społeczności lokalnej to również udział w organizowanych $\mathrm{w}$ mieście imprezach. Ponad połowa badanych $(59,1 \%)$ nie bierze udziału w imprezach organizowanych w Białymstoku. Swój udział zadeklarowała mniejszość, czyli 40,9\% (tabela 5). Oczywiście od razu narzuca się myśl o zbadaniu zależności między udziałem badanych w imprezach organizowanych przez miasto a wykształceniem. I rzeczywiście, związek jest bardzo wyraźny ( $p=0.000$ ). Im lepsze wykształcenie tym liczniejszy udział w wydarzeniach organizowanych przez miasto. Spośród osób z wykształceniem podstawowym w imprezach bierze udział $19,6 \%$ badanych. Dużo więcej, bo 36,2\% respondentów uczestniczących w wydarzeniach miejskich legitymuje się wykształceniem zawodowym. Uczestniczący w imprezach miejskich seniorzy, posiadający wykształcenie średnie stanowią 44,8\% badanych z tej grupy. Proporcjonalnie największą grupą uczestniczącą w aktywnościach miejskich są osoby z wyższym wykształceniem, spośród których 55,7\% przyznaje się do tego faktu.

Silną zależność zanotowano też między uczestnictwem w festynach organizowanych $\mathrm{w}$ mieście a zadowoleniem $\mathrm{z}$ aktualnego życia $(\mathrm{p}=0.000)$. Z grupy osób deklarujących satysfakcję życiową 45,2\% bierze udział w imprezach miejskich, natomiast spośród kohorty respondentów niezadowolonych z własnego życia o udziale w różnych wydarzeniach miejskich mówi $28,2 \%$ badanych. 
Oczywistą rzeczą jest fakt większego udziału we wszelkiego rodzaju imprezach osób, które deklarują dobre zdrowie. Nie inaczej jest w niniejszych badaniach. Zależność jest bardzo widoczna $(\mathrm{p}=0.000)$. Im lepsze zdrowie tym liczniejszy udział w wydarzeniach miejskich. Fakt ten deklaruje 55,6\% seniorów z grupy określającej swoje zdrowie jako dobre i raczej dobre, $36 \%$ badanych z grupy uważającej się za przeciętną i 25,1\% respondentów ze zbiorowości, która swoje zdrowie traktuje jako złe i raczej złe.

Tabela 6. Aktywne działanie w organizacji na terenie miasta

\begin{tabular}{|l|c|c|}
\hline $\begin{array}{c}\text { Czy Pan/Pani aktywnie działa w organizacjach/ } \\
\text { stowarzyszeniach na terenie miasta? }\end{array}$ & N & $\%$ \\
\hline Tak, jestem aktywnym zwykłym członkiem & 62 & 6,3 \\
\hline Tak, jestem aktywny/a będąc w kierownictwie & 16 & 1,6 \\
\hline Jestem członkiem, ale nie udzielam się społecznie & 63 & 6,4 \\
\hline Nie jestem & 839 & 85,6 \\
\hline Ogółem & 980 & 100,0 \\
\hline
\end{tabular}

Źródło: badania własne.

Ciągła aktywność w odróżnieniu od aktywności okazjonalnej wymaga na ogół ram instytucjonalnych. W obrębie tych instytucji działają zazwyczaj osoby o sprecyzowanych zainteresowaniach i posiadający potrzebę aktywności. W prezentowanych badaniach aktywne członkostwo w stowarzyszeniu na terenie miasta Białegostoku zadeklarowało 6,3\% badanych seniorów, a 6,4\% respondentów określiło siebie mianem członka nieudzielającego się społecznie. Dużo mniej, bo 1,6\% zadeklarowało działalność w kierownictwie różnych stowarzyszeń. Zdecydowana większość $(85,6 \%)$ pozostaje jednak poza strukturami działających w naszym mieście stowarzyszeń (tabela 6).

Większą aktywność w działalności instytucjonalnej przejawiają kobiety. Aktywne członkostwo w stowarzyszeniu deklaruje 7,3\% kobiet i 4,7\% mężczyzn. Praca w kierownictwie to również częściej domena kobiet niż mężczyzn, bowiem $2,2 \%$ respondentek działa aktywnie w kierownictwie. To samo wykonuje 0,8\% mężczyzn. Nawet bierne członkostwo w stowarzyszeniu jest bardziej domeną kobiet niż mężczyzn. Należy do stowarzyszenia, lecz nie działa 7,2\% kobiet i 5,3\% mężczyzn. Oczywiście poza stowarzyszeniami w badanej grupie seniorów jest więcej mężczyzn $(89,2 \%)$ niż kobiet $(83,4 \%)$.

Badania ogólnopolskie prowadzone w 1999 r. wskazywały na to, że przynależność do organizacji w starszym pokoleniu jest domeną mężczyzn. Przynależność taką deklarowało około 19\% respondentów i 11\% respondentek (Halicka, Halicki 
2002). W badaniach wykonanych na zlecenie Urzędu Miejskiego w Białymstoku w 2019 r., jak już wyżej wspomniano, 16,7\% kobiet zadeklarowało przynależność do organizacji. To samo uczyniło znacznie mniej mężczyzn $(10,8 \%)$. Widać więc wyraźnie, że potrzeba przynależności do organizacji czy stowarzyszenia częściej występująca dawniej u mężczyzn została w znacznym stopniu sfeminizowana.

Wielkość grupy osób aktywnie działających w stowarzyszeniu jest związana z wiekiem. Im młodsi seniorzy, tym grupa osób aktywnych jest większa. W grupie najmłodszych respondentów (65-69 lat) aktywność zadeklarowało 10\% badanych, zaś w grupie najstarszej (81 i więcej lat) 4,3\%. W kohortach 70-75 i 76-80 mówi o swojej aktywności odpowiednio: 7 i 5,4\% badanych.

Poziom zinstytucjonalizowanej aktywności ankietowanych osób starszych jest silnie powiązany $\mathrm{z}$ wykształceniem $(\mathrm{p}=0.000)$. Wśród osób posiadających wykształcenie podstawowe do aktywnego działania w stowarzyszeniu przyznało się 3,6\%. W grupie respondentów z wykształceniem zawodowym aktywnie udziela się w organizacjach $5,2 \%$, zaś spośród osób posiadających wykształcenie średnie zinstytucjonalizowaną aktywność zadeklarowało 5,6\% badanych. Najbardziej aktywni są absolwenci szkół wyższych. Z tej grupy udziela się w stowarzyszeniach $18,1 \%$ seniorów. Trzeba też wspomnieć o zależności odwrotnej, im gorsze wykształcenie, tym grupa „niezrzeszonych” jest większa. Wśród osób z wykształceniem wyższym stanowią oni 71\%, a wśród najgorzej wykształconych (wykształcenie podstawowe) $94,6 \%$.

Aktywne działanie w organizacjach wiąże się z sytuacją materialną badanych osób ( $\mathrm{p}=0.022$ ). Zauważa się tu następującą zależność, im większa zasobność respondentów, tym ich udział $\mathrm{w}$ aktywnych działaniach $\mathrm{w}$ ramach stowarzyszeń wzrasta. W grupie osób oceniających swoją sytuację materialną jako bardzo dobrą aktywnie działa w organizacjach 15,8\% badanych, w grupie uposażonej na poziomie dobrym odsetek osób aktywnych wynosi 9,5\%. Dwie ostatnie kohorty badanych, z których jedna ocenia swoją sytuację materialną jako przeciętną, a druga jako raczej złą lub złą, legitymują się najmniejszym odsetkiem aktywnych działaczy. W pierwszej aktywność w ramach stowarzyszeń wykazuje 6,6\% badanych, w drugiej 4,2\%.

Każda aktywność człowieka związana jest z jego stanem zdrowia. Kiedy człowiek jest chory, na ogół traci chęć do jakichkolwiek działań. Tak też jest w przypadku deklarowanej przez respondentów aktywności w ramach różnych organizacji. Z grona osób oceniających swoje zdrowie jako dobre i raczej dobre 11,5\% aktywnie działa w stowarzyszeniach. Wśród respondentów uważających swoje zdrowie za przeciętne aktywność deklaruje 6,8\%. Spośród osób określających swoje zdrowie jako złe i raczej złe za aktywne w ramach organizacji uważa się 4,2\%. 


\section{Formy aktywności w czasie wolnym preferowane przez białostockich seniorów}

Tabela 7. Aktywności w czasie wolnym badanych osób starszych

\begin{tabular}{|l|c|c|c|c|c|c|}
\hline \multirow{2}{*}{ Czy poświęca Pan/Pani czas na: } & \multicolumn{2}{|c|}{ Tak } & \multicolumn{2}{c|}{ Nie } & \multicolumn{2}{c|}{ Ogółem } \\
\cline { 2 - 7 } & $\mathrm{N}$ & $\%$ & $\mathrm{~N}$ & $\%$ & $\mathrm{~N}$ & $\%$ \\
\hline Spacery & 771 & 78,7 & 209 & 21,3 & 980 & 100,0 \\
\hline Sport & 196 & 20,0 & 784 & 80,0 & 980 & 100,0 \\
\hline Pracę w ogródku & 497 & 50,7 & 483 & 49,3 & 980 & 100,0 \\
\hline Uprawianie malarstwa, muzyki & 40 & 4,1 & 940 & 95,9 & 980 & 100,0 \\
\hline Prace ręczne, rękodzieło & 213 & 21,7 & 767 & 78,3 & 980 & 100,0 \\
\hline Czytanie gazet & 691 & 70,5 & 289 & 29,5 & 980 & 100,0 \\
\hline Czytanie książek & 627 & 64,0 & 353 & 36,0 & 980 & 100,0 \\
\hline Słuchanie radia & 771 & 78,7 & 209 & 21,3 & 980 & 100,0 \\
\hline Oglądanie telewizji & 946 & 96,5 & 34 & 3,5 & 980 & 100,0 \\
\hline Działalność polityczną & 63 & 6,4 & 917 & 93,6 & 980 & 100,0 \\
\hline Działalność społeczną & 94 & 9,6 & 886 & 90,4 & 980 & 100,0 \\
\hline Działalność w parafii & 149 & 1,2 & 831 & 84,8 & 980 & 100,0 \\
\hline Spotkania w klubie seniora, świetlicy & 156 & 15,9 & 824 & 84,1 & 980 & 100,0 \\
\hline Dokształcanie (UTW) & 63 & 6,4 & 917 & 93,6 & 980 & 100,0 \\
\hline Spotkania z przyjaciółmi & 732 & 74,7 & 248 & 25,3 & 980 & 100,0 \\
\hline Podróże, turystykę & 339 & 34,6 & 641 & 65,4 & 980 & 100,0 \\
\hline Koncert, kino, teatr & 378 & 38,6 & 602 & 61,4 & 980 & 100,0 \\
\hline Korzystanie z Internetu & 419 & 42,8 & 561 & 57,2 & 980 & 100,0 \\
\hline
\end{tabular}

Źródło: badania własne.

Czas wolny stanowi przestrzeń wypełnianą rozmaitymi czynnościami. Z katalogu zaproponowanych w badaniu 18 aktywności najczęściej deklarowaną przez badanych seniorów czynnością w czasie wolnym jest oglądanie telewizji, które zostało wskazane przez 96,5\% respondentów (tabela 7). Na dalszych miejscach znalazły się: słuchanie radia $(78,7 \%)$, spacery $(78,7 \%)$, spotkania z przyjaciółmi (74,7\%), czytanie gazet (70,5\%), czytanie książek (64\%). Najmniej wskazań uzyskały: uprawianie malarstwa, muzyki $(4,1 \%)$, dokształcanie $(6,4 \%)$, działalność polityczna $(6,4 \%)$ i działalność społeczna $(9,6 \%)$.

W ogólnopolskich badaniach prowadzonych przed dwudziestu laty w rankingu najczęściej wskazywanych aktywności prym wiodły również te same czynności, 
które zostały wskazane przez białostockich seniorów w tegorocznych badaniach, jednak odsetek osób wskazujących był znacznie niższy i przedstawiał się następująco: oglądanie telewizji - 84\%, słuchanie radia 64,1\%, czytanie gazet - 56\%, spacery 51,6\%, praca w ogródku - 39\%, spotkania z przyjaciółmi 35\%. Porównanie najczęściej wskazywanych aktywności w obu badaniach skłania do stwierdzenia, że, co prawda, w białostockim sondażu wzmocnieniu uległa frekwencja czynności bierno-receptywnych (oglądanie telewizji, słuchanie radia i czytanie gazet), ale również wyraźnie częściej niż przed dwudziestu laty akcentowane są aktywności fizyczne takie jak spacery i praca w ogródku. Te ostatnie zmiany uznać należy, z punktu widzenia zdrowia i ogólnie jakości życia seniorów, za korzystne. Poza tym wyraźnie na plus zmieniła się deklarowana wielkość kontaktów społecznych. Spotkania z przyjaciółmi wskazywane przez 35\% badanych w 1999 r. za ważną formę swojej aktywności uznało 74,7\% respondentów tegorocznych badań prowadzonych w Białymstoku. A zatem znaczenie czynnika afiliacyjnego w życiu osób starszych wzrosło w sposób iście rewolucyjny.

Najrzadziej wskazywane aktywności w badaniach białostockich należały również do najmniej popularnych czynności wśród respondentów biorących udział w badaniach PTG (1999). Jednak we wszystkich przypadkach wielkość grupy deklarujących wykonywanie wspomnianych czynności w badaniach najnowszych znacznie wzrosła (uprawianie malarstwa, muzyki z 1 do 4,1\%, dokształcanie z 0,3 do 6,4\%, działalność polityczna z 0,7 do 6,4\%, działalność społeczna z 3,8 do 9,6\%). Wszystkie wskazane tu działania były elitarne przed dwudziestoma laty, i takimi pozostały, ale wielkość wykonujących je elit znacznie wzrosła.

Warte bacznej uwagi są zmiany, jakie mają miejsce w zakresie turystycznym i kulturalnym. Przed dwudziestoma laty podróże i turystykę wskazało 5,4\% respondentów, w tegorocznych badaniach grupę uprawiającą podróże i turystykę stanowiło 34,6\% badanych. Z infrastruktury kulturalnej (filharmonia, kino, teatr) korzystało w 1999 r. 2,5\% badanych, a w roku 2019 - 38,6\% respondentów. Zmiany te nastąpiły za przyczyną wielu czynników. Po pierwsze wzrosła zasobność seniorów, po drugie zmieniła się na korzyść infrastruktura kulturalna oraz sieć biur podróży, a także aktywność marketingowa tych instytucji. Ale przede wszystkim zwiększył się znacznie wachlarz potrzeb seniorów (Kubicki 2012; Spyrka-Chlipała 2014; Kalska 2016).

Uzupełnieniem pytania o aktywności w czasie wolnym była prośba o podanie trzech najważniejszych czynności. Najczęściej wskazywana czynność wypełniająca czas wolny, a mianowicie oglądanie telewizji w hierarchii ważności zajęła drugie miejsce. Tak oceniło ją 25,4\% badanych. Najważniejsze dla białostockich seniorów okazują się spotkania z przyjaciółmi (31,3\%), następnie, po oglądaniu telewizji, czytelnictwo $(23,1 \%)$, spacery $(22,2 \%)$, praca w ogródku $(16,2 \%)$ i korzystanie z Internetu $(10,1 \%)$. Najmniej ważne dla ogółu badanych działania to: działalność społeczna $(2,1 \%)$, uprawianie malarstwa, muzyki $(0,7 \%)$, dokształcanie $(0,7 \%)$ oraz działalność polityczna $(0,3 \%)$. Nie wzięto pod uwagę kategorii „inne”, ponieważ ponad $60 \%$ jej zawartości stanowi brak odpowiedzi (tabela 8). 
Tabela 8. Aktywności w czasie wolnym badanych osób starszych a płeć

\begin{tabular}{|l|r|r|r|r|r|r|}
\hline \multirow{2}{*}{ Najważniejsze czynności } & \multicolumn{3}{|c|}{ Kobieta } & \multicolumn{3}{c|}{ Mėzzyzna } \\
\cline { 2 - 7 } & $\mathrm{N}$ & $\% 1$ & $\% 2$ & $\mathrm{~N}$ & $\% 1$ & \multicolumn{1}{c|}{$\%$} \\
\hline Spacery & 133 & 11,4 & 22,1 & 85 & 12,4 & 22,4 \\
\hline Sport & 23 & 2,0 & 3,8 & 26 & 3,8 & 6,9 \\
\hline Praca w ogródku & 106 & 9,1 & 17,6 & 53 & 7,7 & 14,0 \\
\hline Uprawianie malarstwa, muzyki & 4 & 0,3 & 0,7 & 3 & 0,4 & 0,8 \\
\hline Prace ręczne, rękodzieło & 30 & 2,6 & 5,0 & 11 & 1,6 & 2,9 \\
\hline Czytelnictwo & 160 & 13,8 & 26,6 & 66 & 9,6 & 17,4 \\
\hline Słuchanie radia & 44 & 3,8 & 7,3 & 31 & 4,5 & 8,2 \\
\hline Oglądanie telewizji & 131 & 11,3 & 21,8 & 118 & 17,2 & 31,1 \\
\hline Działalność polityczna & 0 & 0,0 & 0,0 & 3 & 0,4 & 0,8 \\
\hline Działalność społeczna & 18 & 1,5 & 3,0 & 3 & 0,4 & 0,8 \\
\hline Działalność w parafii & 33 & 2,8 & 5,5 & 18 & 2,6 & 4,7 \\
\hline Spotkania w klubie seniora, & 3 & 2,7 & 5,2 & 10 & 1,5 & 2,6 \\
\hline świetlicy & & & & & & \\
\hline Dokształcanie (UTW) & 7 & 0,6 & 1,2 & 0 & 0,0 & 0,0 \\
\hline Spotkania z przyjaciółmi & 204 & 7,6 & 33,9 & 103 & 15,0 & 27,2 \\
\hline Podróże, turystyka & 55 & 4,7 & 9,2 & 36 & 5,2 & 9,5 \\
\hline Koncert, kino, teatr & 45 & 3,9 & 7,5 & 15 & 2,2 & 4,0 \\
\hline Korzystanie z Internetu & 56 & 4,8 & 9,3 & 43 & 6,3 & 11,3 \\
\hline Inne & 82 & 7,1 & 13,6 & 63 & 9,2 & 16,6 \\
\hline Ogółem & 1162 & 100,0 & 193,3 & 687 & 100,0 & 181,3 \\
\hline
\end{tabular}

Źródło: badania własne.

(N - odpowiedzi; \% 1 - procent z odpowiedzi; \% 2 - procent z obserwacji).

W ogólnopolskich badaniach, prowadzonych przed dwudziestu laty w hierarchii ważności poszczególnych form aktywności oglądanie telewizji, czynność wskazywana przez największą liczbę respondentów, nie uzyskała palmy pierwszeństwa. Za najważniejsze ówcześni seniorzy uznali spacery $(20 \%)$ oraz pracę w ogródku (19\%). Takie aktywności jak działalność polityczna czy dokształcanie nie pojawiły się w ogóle w rankingu.

Zestawienie rankingu aktywności, którym seniorzy poświęcają swój czas, z listą aktywności najważniejszych z obu badań (z roku 1999 i 2019) pozwala na dokonanie paru obserwacji. Widać wyraźnie, że obecnie osoby starsze dużo więcej czasu poświęcają na aktywności społeczno-kulturalne i sportowo-rekreacyjne niż to 
miało miejsce przed dwudziestu laty. Jednocześnie w hierarchii ważności wykonywanych przez seniorów aktywności zmiany są nieznaczne. Znacznie większe grupy seniorów niż dawniej chodzą do teatru i filharmonii, uprawiają sport i są aktywne turystycznie, a hierarchia ważności czynności wolnoczasowych w zasadzie się nie zmieniła. Wydaje mi się, że na styl życia seniorów duży wpływ mają czynniki zewnętrzne (np. telewizja, marketing, reklama), które kreują nowe potrzeby u seniorów, natomiast hierarchia wartości powiązana jest z czynnikami wewnętrznymi (świadomościowymi), które zmieniają się dużo wolniej.

Przy szukaniu związku najważniejszych czynności w czasie wolnym z płcią badanych, ich wiekiem, wykształceniem, zadowoleniem $\mathrm{z}$ aktualnego życia oraz stanem zdrowia zauważono, że mamy do czynienia w zasadzie w każdym przypadku z zamkniętym katalogiem pięciu czynności wolnoczasowych uważanych za najważniejsze. Zmieniają się jedynie ich pozycje w rankingu w zależności od zmiennej, z którą są krzyżowane. Te czynności to: spacery, praca w ogródku, czytelnictwo, oglądanie telewizji oraz spotkania z przyjaciółmi. Kiedy badaną zbiorowość podzielimy według płci, stwierdzamy w każdej z wydzielonych części trochę inną hierarchię preferencji. Kobiety na pierwszym miejscu stawiają spotkania z przyjaciółmi. Wskazuje na nie 33,9\% respondentek. Na drugim miejscu plasuje się czytelnictwo $(26,6 \%)$. Kolejne dwie pozycje to spacery $(22,1 \%)$ i oglądanie telewizji (21,8\%). Ostatnią z najczęściej wymienianych aktywności jest praca w ogródku. Za jedną z trzech najważniejszych czynności uważa ją 17,6\% badanych kobiet. U mężczyzn najwięcej wskazań uzyskało oglądanie telewizji (31,1\%). Trochę mniejszą popularnością cieszą się spotkania z przyjaciółmi $(27,2 \%)$. Spacery to trzecia spośród pięcioelementowego katalogu czynność, której poświęca się $22,4 \%$ badanych seniorów. Na czwartym i piątym miejscu są: czytelnictwo $(17,4 \%)$ oraz praca w ogródku (14\%). Widać więc wyraźnie, że dla kobiet aktywności o charakterze afiliacyjnym są dużo ważniejsze niż dla mężczyzn, chociaż ci również spotkania z przyjaciółmi sytuują na drugim miejscu w katalogu własnych preferencji. Kobiety w dużo większym stopniu niż mężczyźni korzystają z aktywności, która zapewnia rozwój intelektualny, a mianowicie czytelnictwa (odpowiednio 26,6\% oraz 17,4\%). Panie rzadziej też niż panowie poddają się uproszczonym formom zagospodarowywania wolnego czasu, w których aktywność intelektualna ograniczona jest do minimum, a mianowicie oglądaniu telewizji (odpowiednio: 21,8 i 31,1\% wskazań). Sięgając do aktywności spoza kanonicznego katalogu, a mianowicie: podróże i turystykę, koncert, kino i teatr oraz korzystanie z Internetu trzeba powiedzieć, że kobiety są tu wyraźnie aktywniejsze od mężczyzn.

Wystarczy uważna obserwacja zachowań ludzi starych, by stwierdzić, iż im człowiek jest starszy tym mniej aktywny. Potwierdzają to również wyniki naszych badań. W przypadku trzech spośród pięciu działań uznanych za najważniejsze aktywność seniorów maleje. Spotkania z przyjaciółmi tak popularne w grupie wieku 65-69 lat (34,4\% wskazań) wśród najstarszych seniorów (80 i więcej lat) praktykowane jest przez 25,4\%. Czytelnictwo spada z 25,9\% wskazań wśród 
najmłodszych seniorów do 15,2\% w grupie (80 lat i więcej). Pracę na działce wskazało 19\% osób z najmłodszej grupy wieku (65-69 lat) i 13,8\% z najstarszej (80 lat i więcej). Wzrasta wraz z wiekiem procent respondentów uważających za najważniejszą czynność wolnoczasową oglądanie telewizji. Rośnie on z 18,8\% w grupie najmłodszej do 32,6\% w grupie najstarszej. Wydaje się to rzeczą naturalną, ponieważ czynność ta nie wymaga wysiłku fizycznego ani specjalnego wysiłku intelektualnego. Natomiast zastanawiający jest fakt wzrostu wraz $\mathrm{z}$ wiekiem popularności spacerów. Ten rodzaj aktywności uprawia 21,8\% osób w grupie 65-69 lat i 26,1\% badanych z kohorty 80 lat i więcej. Może się to wiązać z większą ilością wolnego czasu czy też świadomością potrzeby ruchu w późnej starości.

Wykształcenie staje się czynnikiem różnicującym poziom aktywności przede wszystkim w zakresie działań wymagających pewnego wysiłku intelektualnego, a takim jest przede wszystkim czytelnictwo. Wśród osób z wykształceniem podstawowym tę formę wypełniania wolnego czasu preferuje 15,5\% badanych, wśród osób z wykształceniem zawodowym jeszcze mniej, bo 12,9\%, ale absolwenci szkół średnich i wyższych oddają się czytaniu książek i prasy o wiele częściej (odpowiednio: 27 i 33\% badanych). Natomiast grupa osób preferujących oglądanie telewizji zmniejsza się wraz wyższym poziomem wykształcenia. Spośród osób posiadających wykształcenie podstawowe 35,7\% osób zadeklarowało oglądanie telewizji. Absolwenci szkół zawodowych, którzy wskazali na ten sposób wypełniania wolego czasu, stanowią 28,4\% respondentów tej grupy. Najrzadziej oglądają telewizję osoby z wykształceniem średnim i wyższym (odpowiednio: 21,4 i 20,8\%). Pracę w ogródku częściej preferują osoby z wykształceniem średnim i wyższym $(18,9$ i 18,6\%) niż z wykształceniem podstawowym i zawodowym (13,1 i 12,2\%). Pozostałe czynności z określonego wcześniej katalogu (spacery oraz spotkania z przyjaciółmi) są preferowane przez grupy respondentów niezależnie od wykształcenia w równym stopniu.

Zadowolenie $\mathrm{z}$ aktualnego życia również wiąże się $\mathrm{w}$ jakiś sposób z preferencjami najważniejszych czynności wolnoczasowych. Chodzi tu przede wszystkim o pracę w ogródku, oglądanie telewizji i spotkania z przyjaciółmi. Osoby zadowolone z życia dużo chętniej zajmują się pracą na działce $(18,1 \%)$ niż osoby nieusatysfakcjonowane $(10,6 \%)$. Być może obcowanie z naturą służy budowaniu wewnętrznej harmonii, do której osoby nieusatysfakcjonowane mają mniejszą skłonność. Niezadowoleni ze swojego życia respondenci bardziej preferują oglądanie telewizji $(34,3 \%)$ niż osoby życiem usatysfakcjonowane $(22,4 \%)$. Wydaje się, że niewymagająca większego wysiłku czynność jest bardziej odpowiednia dla ludzi, którzy nie potrafią znaleźć wewnętrznej integracji. Również skłonności afiliacyjne są większe u osób zadowolonych ze swojego życia niż u tych niezadowolonych, czego dowodem jest fakt, że 33,3\% badanych spośród respondentów usatysfakcjonowanych swoim życiem chętnie spotyka się z przyjaciółmi, a wśród niezadowolonych podobna postawa dotyczy $25,3 \%$ badanych. 


\section{Zakończenie}

Wyniki zaprezentowanych wyżej badań wskazują, że bardziej aktywne w starości są osoby zdrowsze, lepiej wykształcone, z lepszym zabezpieczeniem materialnym, zadowolone z życia. Aktywność społeczna jest też bardziej domeną kobiet niż mężczyzn oraz w większym stopniu dotyczy seniorów z młodszych kohort wieku. Oczywiście zmienne niezależne proste, jakimi są wiek i płeć, wpływają na aktywność. Tutaj kierunek związku jest jasno określony. Trochę inaczej jest ze zdrowiem, wykształceniem, zabezpieczeniem materialnym i satysfakcją życiową. Test chi kwadrat wykazał silne związki między tymi zmiennymi a aktywnością społeczną. Ale czy to oznacza, że to one wpływają na aktywność? Wydaje się, iż związek ten jest dwukierunkowy. Przecież aktywność fizyczna człowieka może poprawić mu zdrowie. Trzeba wykazać się daleko idącą aktywnością, aby w późnym wieku podnieść, co prawda w sposób nieformalny, poziom swojego wykształcenia, nie mówiąc już o tworzeniu życiowej bazy materialnej czy skutecznym poszukiwaniu satysfakcji życiowej. Oprócz tego aktywne zaangażowanie w życie jest jednym z trzech komponentów proponowanej przez Rowe i Kahna koncepcji pomyślnego starzenia się (Halicki 2010). Artur Oppman w swoich Legendach warszawskich pisał, że nie dukat daje szczęście, ale praca i zdrowie.

\section{Bibliografia}

Baltes P. B. (1996) Uber die Zukunft des Alterns. Hoffnung und Trauerflor w: Produktives Leben in Alter, M. M. Baltes, L. Montada (Hrsg.), Frankfurt, Campus, s. 29-68.

Czerepaniak-Walczak M. (2007) Od próżniaczenia do zniewolenia - w poszukiwaniu dyskursów czasu wolnego w: Pedagogika społeczna. Debata. Podręcznik akademicki, t. 2, E. Marynowicz-Hetka (red.), Warszawa, Wydawnictwo Naukowe PWN, s. 219-236.

Gagacka M. (2007) Czas wolny studentów - preferencje i uwarunkowania w: Czas wolny - uwarunkowania społeczno-ekonomiczne i przyrodnicze, K. Ciżkowicz, M. Sobczak (red.), Bydgoszcz, Wydawnictwo Uczelniane WSG, s. 121-132.

Halicka M., Halicki J. (2002) Integracja społeczna i aktywność ludzi starych w: Polska starość, B. Synak (red.), Gdańsk, Wydawnictwo Uniwersytetu Gdańskiego, s. 189-218.

Halicki J. (2010) Obrazy starości rysowane przeżyciami seniorów, Białystok, Wydawnictwo Uniwersytetu w Białymstoku.

Kubicki P. (2012) Uczestnictwo ludzi starych $w$ życiu środowiska lokalnego w: Raport na temat sytuacji osób starszych $w$ Polsce, P. Błędowski, B. Szatur-Jaworska, Z. Szweda-Lewandowska, P. Kubicki (red.), Warszawa, Instytut Pracy i Spraw Socjalnych, s. $130-172$. 
Mossakowska M., Więcek A., Błędowski P. (2012) Aspekty medyczne, psychologiczne, socjologiczne i ekonomiczne starzenia się ludzi w Polsce, Poznań, Termedia, Wydawnictwa Medyczne.

Piotrowski J. (1973) Miejsce człowieka starego w rodzinie i społeczeństwie, Warszawa, Państwowe Wydawnictwo Naukowe.

Rynkowska D. (2016) Rola i znaczenie aktywności społecznej seniorów, „Annales Universitatis Mariae Curie-Skłodowska", Sectio I ,Vol. XLI, nr 2, s. 91-101.

Sadowski A. (1981) Przejawy ruraryzacji miasta uprzemysłowionego (na przykładzie Białegostoku), Białystok, Sekcja Wydawnicza Filii UW.

Sadowski A. (2006) Białystok. Kapitał społeczny mieszkańców miasta, Białystok, Wydawnictwo Wyższej Szkoły Ekonomicznej.

Spyrka-Chlipała R. (2014) Uwarunkowania i struktura potrzeb seniorów, Roczniki Teologiczne T. LXI, z. 1., s. 235-247.

\section{Źródła internetowe}

Gosik B. (2016) Formy spędzania czasu wolnego starszych osób w województwie łódzkim, „Space - Society - Economy”, nr 14, https://doi.org/10.18778/1733-3180.14.08 [dostęp: 2.12.2019].

Kalska J. (2016) Seniorzy a młodsze pokolenia - problemy życia codziennego, Komunikat z badań nr 161/201, https://www.cbos.pl/SPISKOM.POL/2016/K_161_16.PDF [dostęp: 2.12.2019]. 